\title{
DINAMIKA KEHIDUPAN MANUSIA DAN KONDISI SUMBERDAYA ALAM DAERAH ALIRAN SUNGAI
}

\author{
Elvi Zuriyani \\ Program Studi Pendidikan Geografi STKIP PGRI Sumbar \\ Pephy27@gmail.com
}

\begin{abstract}
The purpose of writing this article is to give an overview of watershed damage that has occurred, which also led to the occurrence of natural disasters. Watershed damage that occurs due to the interaction between human and natural resources show that the interaction is negative in the end will result in damage and natural disasters. This paper is a literature review on the analysis of the facts that occurred on the field of natural resource conditions watersheds, as well as in the analysis of the theories associated with pegelolaan DAS. Based on the problems and phenomena of watershed degradation that has occurred in recent years, it is necessary efforts and strategies for watershed management that are useful for the realization of the sustainability of the watershed for the present and future. Cooperation between the public and the government in watershed management is the key factor required. The government must be able to move the various stakeholders in the management of natural resources, including natural resources watersheds, through policies, strategies, and programs to both short term and long term.
\end{abstract}

Keywords: dynamics, human, watershed resources.

Abstrak

Tujuan penulisan artikel ini adalah untuk memberikan gambaran mengenai kerusakan DAS yang telah terjadi, yang juga mengakibatkan terjadinya bencana alam. Kerusakan DAS yang terjadi akibat adanya interaksi antara manusia dengan sumberdaya alam menunjukkan, bahwa interaksi yang bersifat negative pada akhirnya akan mengakibatkan kerusakan dan bencana alam. Tulisan ini merupakan kajian literatur yang di analisis dengan fakta-fakta lapangan yang terjadi mengenai kondisi sumberdaya alam daerah aliran sungai, serta di analisis dengan teori-teori terkait dengan pegelolaan DAS. Berdasarkan permasalahan dan fenomena degradasi DAS yang telah terjadi belakangan ini, maka diperlukan upaya-upaya dan strategi untuk pengelolaan DAS yang berguna demi terwujudnya keberlanjutan DAS untuk masa sekarang dan masa yang akan datang. Kerjasama antara masyarakat dan pemerintah dalam pengelolaan DAS menjadi kunci utama yang diperlukan. Pemerintah harus dapat menggerakkan berbagai stakeholder dalam rangka pengelolaan SDA, termasuk SDA daerah aliran sungai, melalui kebijakan, strategi, dan programprogramnya baik jangka pendek maupun jangka panjang.

Kata Kunci: dinamika, manusia, sumberdaya DAS.

\section{PENDAHULUAN}

Sumberdaya alam merupakan semua kekayaan berupa benda mati maupun benda hidup yang terdapat di bumi yang dapat dimanfaatkan untuk memenuhi kebutuhan hidup manusia. Tekanan terhadap sumberdaya alam sangat besar seiring dengan tuntutan manusia untuk memenuhi kebutuhan hidupnya. Upaya-upaya untuk memenuhi kebutuhan hidup ini akan terus menerus dilakukan seiring dengan pertumbuhan manusia yang juga terus meningkat. Dalam proses pembangunan manusia sangat berperan aktif dalam proses pemanfaatan sumberdaya alam. 
Manusia sangat bergantung pada sumberdaya alam dan kelestarian sumberdaya alam sangat dipengaruhi oleh aktivitas manusia.

Daerah aliran sungai merupakan salah satu sumberdaya alam yang begitu kompleks dan terdiri dari berbagai komponen yang menyusunnya. Komponen tersebut terdiri dari sumberdaya vegetasi (hutan), tanah, dan air (sungai beserta anak-anak sungai), serta manusia yang terdapat pada kawasan tersebut sebagai pengguna ruang beserta sumberdaya alam yan terdapat didalamnya. Yang mana ekosistem DAS bagian hulu mempunyai keterkaitan yang sangat erat dengan ekosistem DAS pada bagian hilir.

Dharma (2006) mengatakan bahwa salah satu bentuk permasalahan air di Indonesia adalah ditandai dengan kondisi lingkungan yang tidak kondusif sehingga makin mempercepat kelangkaan air. Kerusakan lingkungan antara lain diakibatkan oleh terjadinya degradasi daya dukung DAS hulu akibat kerusakan hutan yang tidak terkendali sehingga luas lahan kritis di Indonesia sudah mencapai 18,5 juta hektar. Peningkatan jumlah DAS kritis, dari 22 pada tahun 1984, hingga menjadi 59 pada tahun 1998. Hal ini yang mengakibatkan turunnya kemampuan DAS untuk menyimpan air di musim kemarau sehingga frekuensi dan besaran banjir semakin meningkat serta sedimentasi yang semakin tinggi mengakibatkan pendangkalan di waduk dan sungai sehingga menurunkan daya tampung dan pengalirannya.

Selanjutnya pada tahun 1999, terdeteksi bahwa 470 DAS di Indonesia, 62 diantaranya dalam kondisi kritis yang diprediksi dari perbandingan aliran maksimum dan minimum sungai-sungai yang sudah melampaui batas normalnya. Keadaan ini diperparah dengan degradasi dasar sungai akibat penambangan bahan galian golongan $\mathrm{C}$ di berbagai sungai di Jawa, Bali, NTB, dan Sumatera Barat yang telah mengakibatkan struktur dan fungsi prasarana dan sarana di sepanjang sungai rusak (Dharma, 2006).

Berdasarkan Kompas (2007), dikatakan bahwa Sebanyak tujuh dari 30 daerah aliran sungai (DAS) di Provinsi Sumatera Barat dalam kondisi kritis. Peladangan berpindah, pembalakan liar, dan penebangan tanpa dilakukan konservasi lahan secara baik, menjadi penyebab utama rusaknya daerah aliran sungai tersebut. Data yang diperoleh dari Badan Pengelola DAS Agam Kuantan, 
tujuh DAS yang berada dalam kondisi kritis adalah DAS Rokan, DAS Kampar, DAS Kuantan-Indragiri, DAS Batanghari, DAS Masang, DAS Tarusan, dan DAS Arau. DAS Kuantan-Indragiri mencakup 10 wilayah kota/kabupaten di Sumatera Barat, Kabupaten Solok, Kota Solok, Kabupaten Tanah Datar, Kabupaten Agam, Kabupaten Sawahlunto-Sijunjung, dan Kota Sawah Lunto. DAS Kuantan-Indragiri merupakan wilayah yang paling luas mengalami kerusakan, yaitu seluas 855.712 hektar. Disusul DAS Batanghari seluas 818.400 hektar. Sedangkan DAS Masang, kerusakannya mencapai luasan 241.243 hektar. Untuk wilayah DAS yang memiliki kerusakan cukup kecil adalah DAS Tarusan, seluas 51.740 hektar.

Rusaknya DAS di Sumatera Barat tentunya terkait dengan kerusakan hutan yang saat ini telah mencapai 53.000 hektar tiap tahun-nya. Ini diakibatkan oleh penebangan liar, perluasan areal perkebunan sawit, Hak Pengusahaan Hutan (HPH), dan kegiatan pertambangan, sehingga menyebabkan berkurangnya ketersediaan air bagi penduduk. Berbagai kebijakan pemerintah untuk mempertahankan ketersediaan air bagi penduduk, bagai "dua sisi tembok besar'. Satu sisi air dilihat sebagai fungsi ekonomi hingga dieksploitasi, sedangkan satu sisi lainnya air menjadi hak masyarakat, sehingga mereka bisa memperoleh air sehat dan bersih. Berkurangnya ketersediaan sumber daya air di Sumbar juga terkait banyak sungai-sungai yang tercemar antara lain adanya penambangan mercuri seperti di DAS Batang Hari. Kemauan pemerintah daerah untuk mempertahankan kawasan sebagai daerah tangkapan air juga rendah, ditandai ekstambang batu bara Ombilin di Sawahlunto justru `disulap` menjadi kawasan pariwisata (Antara, 2009).

Fakta dilapangan menunjukkan bahwa bentuk interaksi antara manusia dan lingkungannya (khususnya komponen ekosistem DAS), merupakan hubungan yang saling terkait dan tidak akan bisa dihentikan, karena bagaimanapun manusia akan selalu membutuhkan sumberdaya alam untuk kehidupannya. Namun bentuk pemanfaatan yang negative, seperti pembukaan lahan dengan membakar, pencemaran DAS oleh limbah pertanian, limbah industry dan kegiatan rumah tangga pada akhirnya akan semakin memperburuk sumberdaya alam dan lingkungan yang pada akhirnya mengakibatkan bencana alam. Berbagai bencana 
alam yang sering terjadi akibat rusaknya sumberdaya DAS adalah penurunan kualitas air akibat pencemaran, banjir, erosi, dan kekeringan.

Kondisi DAS yang telah rusak ini juga semakin diperparah dengan adanya perubahan sistim tata pemerintahan dari sentralisasi menjadi desentralisasi yang dikenal dengan otonomi daerah. Sumberdaya terus saja dieksploitir, tanpa melihat akibat yang ditimbulkan dengan alasan peningkatan Pendapatan Asli Daerah (PAD).

Untuk dapat memperbaiki kondisi kemerosotan sumberdaya alam ini, tentunya perlu dilakukan upaya-upaya yang sangat kompleks terkait dengan sumberdaya alam DAS yang juga merupakan ekosistem yang sangat kompleks. Kerjasama antar daerah yang dilewati oleh DAS, serta kepedulian pemerintah dan masyarakat akan masa depan daerah aliran sungai ini akan sangat mempengaruhi bagian hilir DAS yang merupakan kawasan yang diperuntukan bagi kawasan budidaya dan secara keseluruhan akan berpengaruh terhadap kondisi lingkungan. Berdasarkan permasalahan diatas, maka perlu dikaji gambaran mengenai kerusakan DAS yang telah terjadi yang juga mengakibatkan terjadinya bencana alam, dan bagaimana interaksi yang terjadi antara sumberdaya alam dengan manusia.

\section{PEMBAHASAN}

\section{Interaksi Antara Manusia Dengan Sumberdaya Alam DAS}

Dalam suatu lingkungan hidup yang baik, terjalin suatu interaksi yang harmonis dan seimbang antar komponen-komponen lingkungan hidup. Stabilitas keseimbangan dan keserasian interaksi antar komponen lingkungan tersebut tergantung pada usaha manusia. Karena manusia adalah komponen lingkungan hidup yang paling dominan dalam mempengaruhi lingkungan. Begitu juga sebaliknya, lingkungan pun mempengaruhi manusia. Sehingga terdapat hubungan yang saling mempengaruhi antar manusia dan lingkungan hidupnya. Inilah yang merupakan interaksi antara manusia dan lingkungan (Husein, 1995).

Salah satu bentuk hubungan dan interaksi antara manusia dengan lingkungan adalah meningkatnya pertumbuhan penduduk yang pada akhirnya akan meningkatkan pula penggunaan ruang oleh manusia, baik itu untuk tempat tinggal 
maupun untuk mencari nafkah berupa pemanfaatan lahan untuk pertanian dan ladang. Seiring dengan pertambahan penduduk dan kebutuhan yang semakin meningkat, maka tekanan terhadap sumberdaya lahan dan perubahan penggunaan lahan juga akan semakin meningkat di kawasan lindung. Areal pertanian di sepanjang bantaran sungai dan pada areal-areal terjal semakin banyak dijumpai. Bahkan kawasan lindung juga diperuntukkan oleh masyarakat untuk areal permukiman. Akibatnya areal pertanian dan permukiman semakin meluas sedangkan kawasan lindung akan semakin berkurang.

Degradasi DAS yang terjadi juga diakibatkan oleh mayoritas masyarakat peladang berpindah menanam tanaman bukan tanaman keras di lahan-lahan yang sudah kritis. Mereka menanam palawija yang notabene bukan merupakan tanaman yang baik untuk mengikat air. Kepala Badan Pengelola DAS Agam Kuantan mengatakan bahwa mereka tidak memiliki kekuatan untuk memaksa pemerintah setempat memperbaiki kerusakan lahan. Mereka hanya bisa memberikan masukan untuk melaksanakan perbaikan lahan tersebut. Kesulitan untuk melakukan rehabilitasi lahan, selain karena permasalahan dana, baik dari pusat maupun daerah melalui Anggaran Pendapatan Belanja Daerah, juga karena perilaku masyarakat lokal yang kurang sigap untuk merehabilitasi lahan kritis tersebut (Kompas, 2007).

Data dari Bapedalda Sumbar (2008), juga menunjukkan bahwa kerusakan lahan di Sumatera Barat terjadi akibat pemanfaatan lahan yang terlalu ekstrim dalam mengeksplorasi, eksplotasi, produksi, dan perlakuan yang sifatnya disengaja seperti kegiatan membakar lahan dan hutan, meracuni tanah (pembuangan limbah cair), dan lain sebagainya. Kerusakan lahan akibat ekploitasi dan produksi yang akhir - akhir ini menjadi kekhawatiran kita di Sumatera Barat khususnya, di indonesia ini umumnya, adalah kerusakan lahan kawasan hutan. Pembakaran lahan hutan setelah aktifitas produksi dan ekploitasi hasil kekayaan hutan telah menurunkan fungsi utama dari hutan itu sendiri, yakni sebagai penghasil udara bagi seluruh makhluk hidup di alam ini.

Terjadinya kerusakan terhadap lahan dan hutan telah berdampak terhadap terbentuknya lahan-lahan kritis yang sangat tidak memungkinkan untuk dimanfaatkan secara optimal. Secara umum, lahan kritis ini dapat dikelompokkan atas 4 kelas kekritisan yakni lahan yang berpotensi kritis, agak kritis, kritis, dan sangat kritis. Lahan-lahan yang terkategori 
kritis dan sangat kritis di Propinsi Sumatera Barat mencapai 510.854,6 ha atau 15,61\%. Sedangkan lahan yang terkategori agak kritis mencapai 1.351 .101 ha atau 41,30 \% dan yang berpotensi kritis 1.409.866 ha atau 43,09\%. (Dinas Kehutanan Propinsi Sumbar, 2006 dalam Bapedalda, 2008).

Hal tersebut yang pada akhirnya mengakibatkan kerusakan akan sumberdaya alam DAS tidak dapat dihindari lagi, yang pada akhirnya juga meningkatkan potensi bencana alam, seperti meningkatnya erosi tanah dan sedimentasi serta terjadinya banjir pada musim hujan dan kekeringan pada musim kemarau. Salah satu bencana alam yang sering terjadi pada wilayah Sumatera Barat adalah bencana alam banjir yang disertai oleh longsor atau disebut juga dengan galodo. Bencana alam ini tidak hanya terjadi satu kali saja namun telah sering kali terjadi. Salah satu kasus yang pernah terjadi adalah kasus banjir bandang di Kabupaten Tanah Datar pada Maret 2009 yang lalu.

Sebagai wilayah dengan potensi sumberdaya alam yang besar, dan dengan mata pencarian penduduk terbesar adalah pertanian (bekerja di sector agraris), maka Kabupaten Tanah Datar, wilayah yang berada diantara dua Gunung (Gunung Marapi dan Gunung Singgalang) ini merupakan wilayah yang berpotensi terkena bencana alam banjir bandang (galodo). Bencana ini bukan yang pertama kali terjadi, pada tahun 1979 juga pernah terjadi bencana alam yang sama pada wilayah ini. Beberapa wilayah yang terkena bencana alam banjir bandang (galodo) ini adalah Kecamatan Sungai Tarab, Kecamatan Sungayang, Kecamatan Pariangan, Kecamatan Salimpauang, Kecamatan Padang Gantiang, Kecamatan Tanjung Emas, Kecamatan Lintau Buo, dan Kecamatan Tanjung Baru.

Wilayah yang paling parah terkena bencana alam banjir bandang adalah pada Kecamatan Sungai Tarab Nagari Pasie Laweh. Kerusakan sarana dan prasarana akibat bencana alam ini mencapai Rp 10.750.000.000 serta korban jiwa. Adapun penyebab terjadinya banjir bandang ini dipicu oleh hujan yang terus menerus terjadi yang mengakibatkan terjadinya tumpukan air berupa telaga-telaga di lereng Gunung Marapi. Kandungan air semakin besar sehingga dinding-dinding telaga tidak sanggup menahan tekanan air. Akibatnya terjadilah longsor (air deras dan cukup besar) yang kemudian mengalir melalui sungai batang Bangkahan yang 
bermuara di Batang Selo. Air bah membawa lumpur, pepohonan, bebatuan dan melanda rumah masyarakat sekitar pinggiran sungai sepanjang 30 KM (Antara, 2009).

Berdasarkan kasus yang terjadi, maka dapat dikatakan bahwa proses perubahan penggunaan lahan, selain menghasilkan manfaat yang dapat dinikmati oleh masyarakat juga tidak lepas dari resiko terjadinya kerusakan lahan akibat erosi, pencemaran lingkungan, banjir dan lainnya. Erosi yang tinggi, banjir pada musim penghujan tidak hanya menimbulkan dampak negatif pada aspek bio-fisik sumberdaya alam dan lingkungan tetapi juga berdampak pada aspek sosial ekonomi masyarakat. Erosi dan banjir dapat menurunkan kualitas dan kuantitas sumberdaya alam. Produksi pertanian, perikanan dan penggunaan sumberdaya alam yang berkaitan dengan air akan menurun.

Pemanfaatan segenap komponen ekosistem DAS (air, vegetasi/hutan, dan lahan) oleh masyarakat untuk kepentingan social ekonomi tanpa memperhatikan kesimbangan dan kelestarian lingkungan akan berdampak negative bagi kehidupan manusia di kemudian hari. Seperti kasus banjir bandang di Kabupaten Tanah Datar tidak hanya mengakibatkan kerugian bagi masyarakat, namun juga mengakibatkan rusaknya ekosistem yang terdapat pada kawasan DAS tersebut.

Pada peta berikut ini adalah gambaran mengenai distribusi permukiman penduduk yang cenderung bermukim di sekitar sub-sub DAS yang berhulu di kaki Gunung Merapi di Kabupaten Tanah Datar.

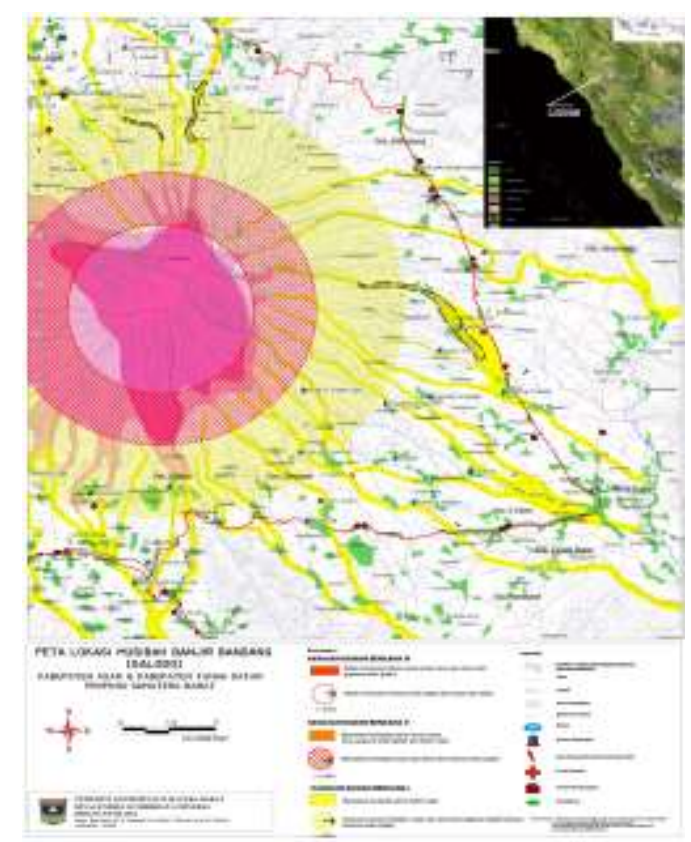




\section{Gambar 1. Peta Lokasi Bermukim masyarakat di kawasan sub-sub DAS Kabupaten Agam dan Kabupaten Tanah Datar}

Berdasarkan peta di atas, terlihat bahwa masyarakat cenderung mendirikan bangunan di sepanjang DAS (sub-sub DAS). Terlihat pada peta, polygon warna hijau menunjukkan distribusi pemanfaatan ruang di sekitar DAS. Manusia yang tinggal dan menetap pada suatu kawasan atau lingkungan yang disekelilingnya memiliki potensi sumberdaya alam yang melimpah cenderung akan memanfaatkan sumberdaya alam tersebut semaksimal mungkin.

Pemanfaatan ekosistem DAS oleh manusia, yang pada akhirnya dapat menimbulkan kerusakan lingkungan, antara lain:

\section{Bidang Kehutanan, Pertanian dan Perkebunan}

Pemberian izin penebangan yang tidak sesuai dengan mekanisme, sampai kepada pengawasan pelaksanaan, sehingga menyebabkan deforestasi yang cukup memprihatinkan. Modus yang sering digunakan adalah pengurusan izin berlokasi di bagian hilir, namun kayu-kayu berasal dari bagian hulu, yang memang secara hukum wilayah tersebut tidak dapat diberikan izin pemanfaatan kayu. Kegiatan ini terus berlangsung sehingga degradasi hutan bagian hulu yang notabene mempunyai potensi yang lebih tinggi tidak dapat terelakan. Selain kegiatan pembalakan yang berkedok ijin tersebut, terdapat juga aktifitas masyarakat yang menebang hutan bagian hulu (ilegal loging) yang cukup memprihatinkan. Beberapa kegiatan operasi yang bersifat represif telah dilaksanakan, namun kegiatan pembalakan liar ini terus berlangsung.

Di Sumatera Barat sendiri, khususnya pada kawasan bencana alam longsor yang terdapat pada peta diatas, aksi penebangan liar (Ilegal loging) di kawasan tersebut telah berlangsung cukup lama. Pengikisan dan erosi telah terjadi minimal 3-4 tahun setelah penebangan. Akibat penebangan hutan ini, sesungguhnya telah dapat dirasakan oleh masyarakat, dengan tanda-tanda yaitu munculnya satwa liar yang berkonflik dengan masyarakat, yang merupakan salah satu indikator. Jika indikator itu tidak diacuhkan maka akan bermertamorfosis, menjadi wabah dan bencana alam. 
Kerusakan hutan lainnya juga terjadi akibat revitalisasi perkebunan dan pertanian di Sumbar. Di saat Sumbar mencanangkan diri sebagai sentra kakao, sawit dan tanaman pertanian lainnya yang cenderung berpola monokultur, pemerintah tidak menyiapkan lahan. Akibatnya masyarakat dan bahkan Pemerintah sendiri membuka lahan dan melakukan konversi. Saat merencanakan proyek tersebut, seolah-olah Pemerintah tidak menghitung ketersediaan lahan yang layak untuk dimanfaatkan, sehingga proyek tersebut pada akhirnya merusak (Pos Metro, 2009). Padahal lahan yang sebenarnya layak untuk dikembangkan untuk budidaya lahan pertanian hanya sekitar 20\%, dari luas wilayah Sumatera Barat yang mencapai 4.229.730 Ha, sedangkan selebihnya merupakan daerah yang cocok untuk konservasi dengan topografi sebagian berbukit dan bergunung.

\section{Penambangan}

Bentuk interaksi lainnya antara manusia dengan sumberdaya alam DAS adalah kegiatan penambangan yang umumnya dilakukan pada kawasan sungai maupun anak-anak sungai. Baik itu penambangan pasir, batuan, maupun bahan galian lainnya seperti emas, dll. Salah satu coontoh yang terjadi adalah kerusakan yang terjadi di DAS Batanghari, tepatnya pada sub DAS Merangin. Kegiatan penambangan terutama dibagian hulu mengakibatkan kualitas sub DAS Merangin Tembesi semakin menurun. Penambangan emas liar atau yang disebut PETI (Penambangan Tanpa Ijin) telah menimbulkan pencemaran air sungai dengan unsur air raksa yang digunakan pada kegiatan penambangan tersebut. Banyaknya kondisi areal yang rusak tidak ada upaya reklamasi, menambah luas deforestasi yang terjadi. Di kabupaten Sarolangun terdapat kegiatan penambangan batubara yang secara geografis terletak di bagian hulu, yang tentunya kegiatan ini perlu dicermati karena dapat merusak kondisi lingkungan, yang akan berdampak kepada penurunan kualitas Sub DAS Merangin. Kegiatan penambangan ini telah berlangsung sejak pemekaran kabupaten pada tahun 2000 (Razak, 2007).

\subsection{Usaha Mengatasi Permasalahan Degradasi DAS}

Permasalahan DAS yang sangat kompleks ini tentunya akan melibatkan banyak pihak dalam upaya untuk mengatasinya. Permasalahan DAS saat ini sangat terkait erat dengan usaha pengelolaan yang dilakukan saat ini. Dalam pengelolaan 
DAS, tergantung dari keberadaan unsure-unsur biofisik maupun unsur non biofisik. Unsur biofisik terdiri dari, vegetasi, hewan, satwa liar, jasad renik, tanah, iklim dan air. Sedangkan unsur nonbiofisik adalah manusia dengan berbagai ragam persoalannya, latar belakang budaya, sosial ekonomi, sikap politik, kelembagaan serta tatanan masyarakat itu sendiri. Pada gambar berikut ini disajikan kerangka pengelolaan sumberdaya alam dengan pendekatan ekosistem DAS.

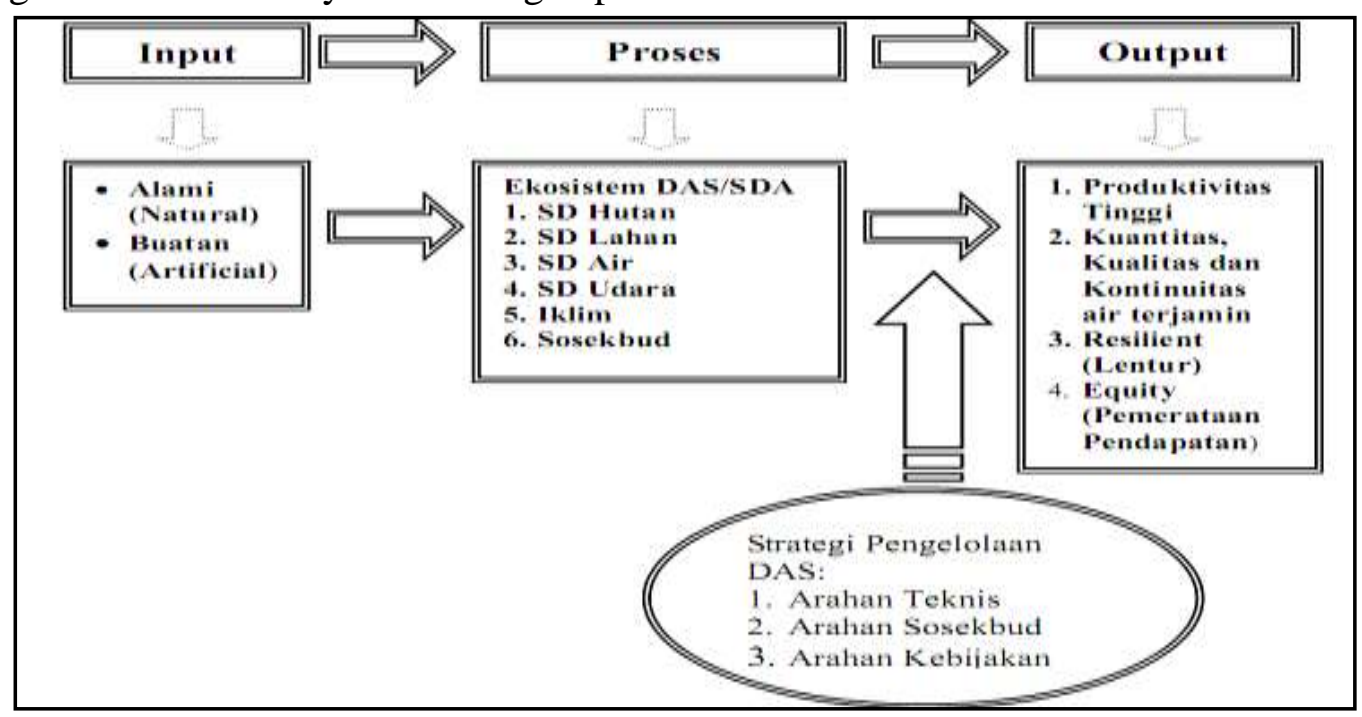

Gambar 2. Pengelolaan SDA dengan pendekatan ekosistem DAS (Dari Makalah Pasca Sarjana IPB. Studi Kasus DAS Ciliwung Hulu. Strategi Pengelolaan DAS Dalam Rangka Optimalisasi Kelestarian SD Air) Kebijakan strategi pengelolaan DAS terdiri dari arahan teknis terkait dengan pengelolaan DAS sebagai sumberdaya alam yang dapat dimanfaatkan oleh manusia. Arahan social budaya terkait dengan fungsi DAS sebagai suatu kawasan yang memiliki fungsi social dan budaya, baik sebagai ruang/tempat hidup bagi manusia dan sebagai lahan untuk mencari nafkah. Berdasarkan arahan kebijakan, DAS tekait dengan kebijakan berbagai pihak terkait, yaitu masyarakat, pemerintah, instansi-instansi terkait, dan pihak swasta. Ketiga arahan dalam strategi pengelolaan DAS ini pada akhirnya akan meningkatkan produktivitas, kuantitas, kualitas, kontinuitas, resilient dan equity (pemerataan pendapatan) berbagai komponen ekosistem DAS (sumberdaya hutan, lahan, air, udara, iklim dan social budaya).

Seperti yang dikemukakan Hufscmitdt (1986), dalam Asdak (2004), bahwa dalam pengelolaan DAS melibatkan tiga dimensi pendekatan analisis. Ketiga dimensi tersebut antara lain adalah: 
1. Pengelolaan DAS sebagai proses yang melibatkan langkah-langkah perencanaan dan pelaksanaan yang terpisah tapi erat dan berkaitan.

2. Pengelolaan DAS sebagai system perencanaan dan pengelolaan dan sebagai alat implementasi program pengelolaan DAS melalui kelembagaan yang relevan dan terkait.

3. Pengelolaan DAS sebagai serial aktivitas yang masing-masing berkaitan dan memerlukan perangkat pengelolaan yang spesifik.

Namun, pada kenyataannya selama ini yang terjadi di lapangan menunjukkan bahwa kegiatan pengelolaan DAS seringkali dibatasi oleh batas-batas yang bersifat politis/administrative (Negara, propinsi, kabupaten). Hal ini mengakibatkan batas-batas ekosistem alamiah kurang banyak dimanfaatkan. Padahal pada kenyataannya bahwa kekuatan alam seperti banjir dan tanah longsor tidak mengenal batas-batas politis tersebut. Peristiwa degradasi lingkungan seperti banjir, tanah longsor, erosi jelas mengabaikan penetapan batas-batas politis tersebut. Beberapa aktivitas pengelolaan DAS yang diselenggarakan di daerah hulu seperti kegiatan pengelolaan lahan yang mendorong terjadinya erosi pada akhirnya dapat menimbulkan dampak di daerah hilir, seperti dalam bentuk pendangkalan sungai atau saluran irigasi karena pengendapan sedimen yang berasal dari erosi di daerah hulu.

Dalam pengelolaan DAS terdapat pihak-pihak terkait yang hendaknya dapat saling bekerjasama dalam kegiatan pengelolaan DAS. Pelaksanaan DAS bagian hulu melibatkan Departemen Kehutanan, Departemen Pertanian, dan Departeman Dalam Negeri. Untuk wilayah tengah dan hilir yang terlibat adalah Departemen Permukiman, dan Prasarana Wilayah, yang mempunyai wewenang mengelola daerah irigasi. Pada wilayah hilir (wilayah pantai), Departemen Kelautan dan Perikanan bertanggungjawab terhadap aspek perikanan, sedangkan Departemen Kehutanan juga bertanggungjawab terhadap pengelolaan hutan pantai. Selanjutnya, juga terdapat Departemen terkait lainnya yang mempunyai kewenangan dalam pengelolaan DAS, yaitu Departeman Perindutrian, Departemen Perindustrian, Departemen Energi dan Sumberdaya Mineral, dan Menteri Negara Lingkungan 
Hidup. Karena itulah, keterlibatan dan wewenang masing-masing departemen di seluruh wilayah DAS adalah saling mengisi. Dalam pengelolaan DAS, yang terpenting adalah penanganan permasalahan kelembagaan dan wewenang pengelolaan sumberdaya dan harus adanya perumusan secara jelas permasalahan biogeofisik (seperti kemerosotan sumberdaya hutan, tanah dan air) serta social ekonomi (seperti konflik pemanfaatan sumberdaya dan peningkatan pendapatan petani).

Namun pada kenyataannya, keseriusan upaya-upaya perbaikan DAS yang telah kritis ini cenderung rendah. Hal ini ditandai dengan masih banyaknya permasalahan kerusakan sumberdaya alam baik di bidang kehutanan, maupun di bidang sumberdaya air dan lahan (tanah). Hal ini terbukti, ketika telah terjadi bencana alam besar dan memakan banyak korban (jiwa maupun harta benda dan kerusakan infrastruktur), barulah semua pihak tersentak dan seolah-olah menyesalkan kejadian ini. Namun terkadang penyesalan ini hanya berlangsung sasaat. Ketika bencana sudah tidak lagi terjadi, dan keadaan perlahan-lahan sudah mulai membaik, kembali terjadinya ketidak acuhan berbagai pihak tersebut. Pemerintah yang seharusnya cepat tanggap dan harusnya menyusun rencana dan strategi pengelolaan yang baik, seakan kembali terlena mengejar target pemasukan daerahnya (PAD). Hal ini juga dipicu oleh status otonomi daerah yang didapatkan oleh masing-masing daerah yang berlomba-lomba memanfaatkan sumberdaya alam daerah masing-masing untuk meningkatkan kesejahteraan daerahnya tanpa memperhitungkan akibat-akibat yang akan terjadi terhadap sumberdaya alam dan lingkungannya di masa sekarang dan di masa yang akan datang.

Dalam era otonomi daerah saat ini, juga terlihat adanya berbagai ketidakselarasan dan ketidaksinkronan antara kebijakan Pemerintah Pusat dengan Pemerintah Daerah. akibatnya terjadi tumpang tindih kebijakan beserta peraturan yang ada dalam bidang kewenangan pemerintah, salah satunya adalah di bidang pengelolaan sumberdaya alam khusunya sumberdaya kehutanan, yang diwujudkan dalam UU Nomor 41 Tahun 1999 tentang kehutanan beserta peraturan pelaksanaan dibawahnya. Dilain pihak, dengan adanya UU Nomor 22 Tahun 1999 yang dijabarkan lebih lanjut dalam PP Nomor 25 Tahun 2000 tentang Kewenangan 
Pemerintah Pusat dan Propinsi sebagai Daerah Otonom, maka dalam pengelolaan hutan pun terbagi dalam kewenangan Pemerintah Pusat, Propinsi dan Kabupaten. Iwanuddin (2003) mengemukakan bahwa konsekuensi dari kebijakan tersebut adalah pengelolaan sumberdaya hutan yang dulunya berdasarkan admisnistrasi dengan DAS sebagai dasar dalam pengelolaan hutan bergeser berdasarkan administrasi pemerintahan sehingga antara satu Kabupaten/Kota dengan Kabupaten/Kota lainnya dalam satu Propinsi pengelolaan hutannya terpisah-pisah dan masing-masing kabupaten/kota memiliki kebijakan pengelolaan hutan sendirisendiri dan koordinasi dengan pihak Pemerintah Propinsi cenderung diabaikan, apalagi dengan Pemerintah Pusat. Kenyataan ini dipicu dengan meningkatnya tuntutan daerah untuk ikut mengelola dan memanfaatkan sumberdaya alam di wilayahnya secara proposional.

Adanya program-program dalam upaya perbaikan DAS yang telah kritis juga telah dilakukan, seperti pengelolaa DAS terpadu (merupakan suatu proses formulasi dan implementasi kebijakan dan kegiatan yang menyangkut pengelolaan sumberdaya alam, sumberdaya buatan dan manusia dalam suatu DAS secara utuh dengan mempertimbangkan aspek-aspek fisik, sosial, ekonomi dan kelembagaan di dalam dan sekitar DAS untuk mencapai tujuan yang diinginkan) yang telah begitu banyak diajukan oleh para pakar, pembentukan forum DAS di tiap-tiap Propinsi, Kabupaten dan Kota, serta pembentukan Badan Pengelolaan DAS sebagai koordinator pengelolaan DAS lintas kabupaten. Namun dalam kenyataannya di lapangan saat ini, terlihat banyak kekurangan dalam hal pelaksanaannya dan para pelakunya sendiri. Keterbatasan dana dan sumberdaya manusia adalah salah satu penyebabnya. Sebagai salah satu contoh, di Sumatera Barat sendiri, pemetaan di kawasan-kawasan yang terkena longsor belum dilakukan, karena terkait dengan keterbatasan dana dan SDM. Selanjutnya, instansi-instansi terkait juga cenderung jalan sendiri-sendiri dan belum adanya koordinasi yang menyeluruh membicarakan masalah kerusakan lingkungan.

Ketidak acuhan pemerintah dan masyarakat ini apabila terus diabaikan dan tidak dirubah maka akan mengakibatkan semakin memperburuk upaya dalam 
membangun interaksi yang lebih baik antara sumberdaya alam dan manusia yang pada akhirnya akan memperburuk kualitas sumberdaya dan lingkungan itu sendiri.

\subsection{Upaya Pengelolaan DAS bagi keberlanjutannya di Masa yang Akan Datang}

Seperti yang telah dikemukakan diatas, hasil dari program-program perbaikan sumberdaya DAS belum dapat dilihat hasilnya. Rencana-rencana kegiatan tersebut seolah-olah hanya merupakan peraturan-peraturan tertulis yang pelaksanaannya begitu lambat bahkan cenderung terkesan sulit untuk dilakukan. Perbaikan DAS yang dilakukan selama ini selalu terkendala pada kekurangan dana dan SDM. Salah satu contoh, adalah dana untuk perbaikan DAS dan pengelolaannya yang disediakan oleh Pemerintah tidak mencukupi sehingga Pemerintah cenderung bergantung pada pinjaman dari luar negeri dari Bank Pembangunan Asia. Hal ini dilakukan karena dana dalam negeri tidak dapat diandalkan untuk memperbaiki DAS yang sampai saat ini sudah mengalami kerusakan sebanyak 59 DAS. Dua DAS yang perbaikannya mengandalkan hutang luar negeri adalah sungai CitanduySegara Anakan (Kabupaten Cilacap Jawa Tengah) dan Sungai Belawan-Deli (Sumatera Utara). Namun upaya penanganan ke 2 DAS ini juga mengalami kendala yakni di Citanduy-Segara Anakan lebih disebabkan adanya sekelompok masyarakat yang khawatir lingkungannya akan terganggu dengan adanya perbaikan di hulu sungai, sementara di Belawan-Deli lebih disebabkan belum selesainya masalah pembebasan lahan. Padahal penanganan kedua sungai itu sudah sangat mendesak untuk mengantisipasi terjadinya kecepatan pengendapan (sedimentasi) yang sering terjadi di muara sungai. Untuk perbaikan DAS Citanduy, Pemerintah telah menyiapkan dua program yakni pembangunan sodetan namun mendapat tentangan keras dari masyarakat di sekitar aliran sungai, serta melakukan konservasi alam di hulu sungai. Padahal sudah ada kajian dari IPB dan ITB menyangkut pembangunan sodetan itu tidak akan mengganggu lingkungan pada masyarakat yang tinggal di sekitar aliran sungai (Dadang, 2007).

Hal ini menunjukkan bahwa hubungan manusia dengan lingkungan juga terkait dengan permasalahan dana, serta tingkat kepedulian masyarakat terhadap keberlanjutan lingkungan. Aksi penolakan yang dilakukan oleh masyarakat sekitar 
DAS atas usaha perbaikan oleh pemerintah menunjukkan bahwa belum terjalinnya saling pengenrtian antara pemerintah dan masyarakat. Entah karena sosialisasi yang memang kurang dari pemerintahnya atau mungkin memang masyarakat yang kurang mengerti dengan lingkungannya.

Untuk permasalahan pendanaan, hendaknya upaya perbaikan DAS tidak perlu mengandalkan utang luar negeri. Sseungguhnya dengan keuntungan yang didapatkan melalui pemanfaataan sumberdaya alam DAS tersebut dapat disisihkan sebanyak 50\% nya untuk biaya perbaikan DAS. Walaupun dana tersebut tidak mungkin mencukupi, namun paling tidak beban pemerintah tidak semakin bertambah dengan utang terhadap pembiayaan perbaikan DAS. Selanjutnya pemerintah juga harus dapat menjalin interaksi yang lebih baik dengan masyarakat, dalam rangka membangunan interaksi manusia yang lebih baik dengan lingkungannya.

Selain itu, program-program prioritas daerah yang secara nyata dapat melakukan perubahan dapat dilaksanakan seperti: Inventarisasi SDA, penelitian potensi dan manfaat SDA; pengembangan IPTEK dan pengelolaan SDA dan lingkungan; Penyiapan dan pengembangan SDM dan organisasi yang professional melalui berbagai training yang terencana; Menyusun berbagai arahan/petunjuk daerah sesuai dengan kondisi dan permasalahan daerah, seperti: tata ruang, konservasi hutan, tanah dan air (pengelolaan kawasan konservasi alam, pengelolaan kawasan lindung seperti hutan mangrove, hutan lindung), pengelolaan daerah resapan air, pengelolaan DAS terpadu, terumbu karang, padang lamun, produksi bersih, termasuk perlindungan atmosfer melalui program langit biru dalam kaintannya dengan pencemaran udara, kebakaran hutan dan efek rumah kaca.

\section{Upaya Membangun Interaksi Yang Lebih Baik Antara Manusia dengan Sumberdaya Alam}

Dalam upaya pengelolaan DAS di masa yang akan datang, maka yang sangat diperlukan adalah dapat membangun interaksi manusia dengan lingkungannya secara lebih baik. Hal ini dapat terwujud dengan membangun suatu hubungan yang baik antar stakeholder yang terlibat dalam permasalahan degradasi sumberdaya alam DAS ini. Hubungan yang baik manusia dengan sumberdaya alam 
adalah terwujud dalam bentuk pemanfaatan dan pengelolaannya. Bukan hanya masyarakat saja, namun juga pihak pemerintah dan instansi-instansi lainnya yang terkait dengan pemanfaatan dan pengelolaan sumberdaya alam DAS ini.

Upaya Pemerintah dalam membangun interaksi antara manusia dengan sumberdaya alam dan lingkungan ini adalah salah satunya dengan meninggalkan dan mengubah praktek maupun prinsip-prinsip lama yang tidak sesuai lagi dengan tuntutan pembangunan di masa sekarang ini (Alikodra, 2001). Beberapa prinsip lama yang perlu dirombak adalah:

1. Bekerja pada kondisi keterbatasan data dan informasi SDA dan lingkungan.

2. Pengelolaan SDA dan lingkungan yang dicirikan dengan praktek-praktek monopolistic dan sentralistik.

3. Mengutamakan kepentingan ekonomi daripada kepentingan ekologi, misalnya menarik banyak investor dengan mengabaikan kendala-kendala maupun aturan di bidang lingkungan hidup, termasuk memasukkan limbah dari luar.

4. Pendekatan pembangunan yang bertumpu pada batas-batas administrative, dengan mengabaikan batasan atau unit ekologi yang sangat penting artinya bagi perencanaan dan implementasi pembangunan.

5. Pembangunan yang kurang terkoordinasi dan terintegrasi dengan tujuan pengelolaan lingkungan hidup.

6. Kurang diperhatikannya fungsi-fungsi ekologi yang mendukung pembangunan, misalnya fungsi hutan mangrove, fungsi daerah resapan, fungsi terumbu karang, fungsi daerah rawa, fungsi lahan gambut, dsb.

Khususnya pada pengelolaan DAS, saat ini hendaknya keterbatasan data dan dana dalam pengelolaan dan perbaikannya ini benar-benar harus ditanggulagi. Hendaknya pemerintah harus memiliki dana khusus yang dapat dipergunakan sewaktu-waktu untuk merehabilitasi sumberdaya alam DAS. Selanjutnya yang sangat perlu dirubah adalah praktek pengelolaan SDA hendaknya tidak dengan praktek-praktek monopolistic dan sentralistik, tapi hendaknya dengan membagibagi pengelolaan SDA tersebut pada instansi terkait dan pada wilayah yang memiliki SDA tersebut. Pada DAS, pengelolaannya tidak dapat dilakukan oleh satu 
instansi saja, seperti misalnya pengelolaan DAS hanya diberikan pada Dinas Kehutanan saja, dan juga tidak dapat dibebankan pada satu wilayah saja. Karena bagaimanapun juga, DAS terdiri dari beberapa sumberdaya alam seperti hutan, air dan lahan yang akan melibatkan banyak departemen. Dan sumberdaya alam DAS juga tidak hanya melewati satu daerah saja, namun melewati banyak wilayah, baik kota, kabupaten, propinsi bahkan Negara. Karena itulah pengelolaannya tidak bisa secara monopolistik dan sentralistik.

Selanjutnya dalam pengelolaan SDA harusnya tidak hanya mengandalkan alasan-alasan ekonomi saja. Kepentingan ekonomi harus dapat dijalankan dengan kepentingan keberlanjutan ekologi. Analisa ekonomi dapat dipergunakan untuk mengkaji kebijakan pemanfaataan SDA. Yang dipergunakan adalah analisis perhitungan biaya kerugian yang akan didapatkan apabila SDA tersebut mengalami kerusakan, dibandingkan dengan keuntungan yang akan didapatkan dengan pemanfaatan SDA tersebut. Hal ini disebut juga dengan prinsip valuasi ekonomi. Sebagai salah satu contoh adalah, bahwa saat ini dalam pemanfaatan sumber daya alam sering terjadi jasa lingkungan sumber daya tersebut belum di hargai secara jelas. Misalnya hutan sering di nilai manfaat kayu nya saja sementara manfaat hutan sebagai pengatur siklus hidrologi belum dinyatakan dengan nilai uang. Upaya menyatakan nilai manfaat semua sumber daya dalam bentuk uang tersebut yang disebut dengan valuasi ekonomi.

Jadi dalam pelaksanaan pembangunan dan dalam rangka pemanfaatan dan pengelolaan SDA, hendaknya tidak hanya bertumpu pada batas-batas administrative saja, namun harus mengikut sertakan batasan atau unit ekologi yang sangat penting artinya bagi perencanaan dan implementasi pembangunan. Pembangunan harus dapat terkoordinasi dan terintegrasi dengan tujuan pengelolaan lingkungan hidup.

Selanjutnya untuk membangun kesadaran diri masyarakat yang hidup di sekitar kawasan DAS, diperlukan adanya upaya pengembangan kesadaran masyarakat. Diantaranya adalah dengan melakukan penyuluhan kesadaran konservasi pada kelompok kelompok masyarakat seperti kelompok pencari kayu bangunan, kelompok pencari kayu bakar, kelompok perambah hutan, kelompok 
pemburu satwa liar, kelompok pencari/pengambil hasil hutan lainnya. Selanjutnya penyuluhan terpadu terhadap masyarakat dengan unsur-unsur terkait juga harus dilakukan. Kemudian, khusus bagi masyarakat di sekitar daerah penyangga, harus adanya pendidikan kader konservasi. Dengan penyuluhan-penyuluhan dan pendidikan yang didapatkan oleh masyarakat, maka pemanfaatan dan pengelolaan SDA khususnya SDA daerah aliran sungai akan berlandaskan pada keberlanjutan fungsi ekologinya, bukan saja bertujuan untuk fungsi ekonomi saja.

Sehubungan dengan era desentralisasi, maka untuk dapat menentukan strategi pengelolaan DAS, dapat diidentifikasi factor-faktor pendukung yakni factor internal dan factor eksternal yang nantinya dapat digabungkan untuk membangun suatu strategi pengelolaan untuk membangun suatu interaksi yang lebih baik. Mengidentifikasi peluang, ancaman, kekuatan, dan kelemahan dalam untuk menentukan strategi pengelolaan DAS. Dengan menggunakan kekuatan (Otonomi daerah, keterkaitan hulu dan hilir DAS, serta komitmen pemerintah dalam pengelolaan DAS), untuk memanfaatkan peluang yang ada (Stakeholder, SDM dan SDA), maka akan menjadi pendukung dalam konteks desentralisasi dengan membuat perencanaan pengelolaan DAS lintas sektoral dan lintas kabupaten yang nantinya menjadi pola pengelolaan DAS antar kabupaten (local). Kekuatan (Otonomi daerah, keterkaitan hulu dan hilir DAS, serta komitmen pemerintah dalam pengelolaan DAS) juga dapat digunakan untuk mengatasi ancaman (yakni ego sektoral dan degradasi lingkungan). Sebaiknya pemerintah Pusat atau Propinsi sebagai fasilitator dalam kelembagaan pengelolaan DAS dalam konteks desentralisasi, memanfaatkan factor kekuatan yang dimiliki melalui kegiatan, sosialisasi, dll, untuk meningkatkan pemahaman masyarakat maupun pemerintah daerah terhadap pengelolaan DAS, sehingga dapat meningkatkan kesadaran dan partisipasi masyarakat dalam kelembagaan pengelolaan DAS lintas wilayah. Klarifikasi dan kejelasan tugas pokok dan fungsi masing-masing lembaga terkait sangat diperlukan dalam pengaturan kewenangan pengelolaan DAS.

Strategi yang dihasilkan dari kelemahan (yakni pengelolaan DAS yang belum terpadu, koordinasi antara Pemda yang masih rendah, kelembagaan pengelolaan DAS yang belum mantap dan keterbatasan anggaran) dapat 
diintegrasikan dengan peluang yang ada yakni SDA, SDM dan seluruh stakeholder yang terlibat. Wilayah DAS yang tidak terbatas oleh wilayah administrasi pemerintahan, dalam pengelolaannya dirasakan sangat perlu termasuk didalamnya mekanisme kerja dan koordinasi antar lembaga. Tugasnya sebagai koordinasi operasional, dapat berbentuk lembaga/instansi (Badan Koordinasi Pengelolaan DAS). Koordinator adalah instansi yang berwenang mengkoordinasikan penyelenggaraan urusan pengelolaan DAS, bukan sebagai pelaksana pengelolaan DAS. Pelaksanaan operasional dan pemeliharaan lingkungan dilaksanakan oleh instansi teknis terkait pada tiap pemerintah kabupaten.

Selanjutnya dibangunlah strategi dengan meminimalkan kelemahan (yaitu pengelolaan DAS yang belum terpadu, koordinasi antara Pemda yang masih rendah, kelembagaan pengelolaan DAS yang belum mantap dan keterbatasan anggaran), untuk menghindari ancaman yang ada (ego sektoral dan degradasi lingkungan fisik). Berdasarkan kedua factor tersebut maka yang harus dilakukan oleh pemerintah adalah menyusun peraturan per UU tentang pengelolaan DAS, dalam bentuk PP, Keppres, Kepmen, SK Gubernur, Perda, dll. Diharapkan perangkat peraturan tersebut dapat dijadikan koridor dalam pengelolaan wilayah dengan DAS sebagai batasannya. Hal inilah yang pada akhirnya dapat dijadikan landasan untuk dapat mengelola SDA demi keberlanjutan di masa sekarang dan dimasa datang, serta untuk dapat membangun interaksi yang lebih baik antara manusia dan sumberdaya alam.

\section{KESIMPULAN}

1. Berdasarkan permasalahan dan fenomena degradasi DAS yang telah terjadi belakangan ini, maka diperlukan upaya-upaya dan strategi untuk pengelolaan DAS yang berguna demi terwujudnya keberlanjutan DAS untuk masa sekarang dan masa yang akan datang.

2. Pemerintah Pusat harus tetap melakukan kontrol terhadap Pemerintah Daerah dalam pemanfaatan dan pengelolaan sumberdaya alam, agar tidak salah dalam pengelolaan yang pada akhirnya berkonsekuensi pada kualitas lingkungan hidup. 
3. Diperlukan program-program prioritas daerah yang secara nyata dapat melakukan perubahan dalam pemanfaatan dan pengelolaan sumberdaya alam DAS.

4. Pemerintah harus dapat menggerakkan berbagai stakeholder dalam rangka pengelolaan SDA, termasuk SDA daerah aliran sungai, melalui kebijakan, strategi, dan program-programnya baik jangka pendek maupun jangka panjang.

5. Diperlukan pengembangan Leadership, yakni menyangkut moral dan etika para pengambil keputusan dibidang pengelolaan SDA dan lingkungannya. Sangat perlu mengubah sikap dan prilaku para pengambil kebijakan tersebut pada tingkat manapun agar tetap dalam koridor pembangunan daerah berwawasan lingkungan.

6. Moral yang baik setiap manusia merupakan factor penentu keberlanjutan pengelolaan SDA. Dengan pendidikan moral dan penumbuhan kesadaran yang baik maka sumberdaya alam dan lingkungan dapat dijaga keberlanjutannya.

\section{DAFTAR PUSTAKA}

Anonim (2009). Kerusakan Hutan Sumbar Capai 53.000 Ha per Tahun. Diakses Tanggal 13 July 2009, dari www.antara-sumbar.com

Anonim (2009). Sikap Abai Sebabkan Bencana, Perubahan RTRW Ancam Hutan. Diakses tanggal 26 July 2009 dari www.posmetropadang.com

Agus. N., dkk. (2003). Strategi Pengelolaan DAS Dalam Rangka Optimalisasi Kelestarian Sumberdaya Air. Studi Kasus DAS Ciliwung Hulu. Makalah Pasca Sarjana IPB.

Alikodra. H. (2001). Pengelolaan Sumberdaya Alam (SDA) dan Lingkungan Bagi Kelestarian PAD. Jurnal Pembangunan Daerah. Edisi II Tahun ke 5. Hal. 15

Asdak. C. (2004). Hidrologi dan Pengelolaan Daerah Aliran Sungai. Gadjah Mada University Press. Yogyakarta

Antara. (2009). Galodo Diawali Suara Bergemuruh. Diakses Tanggal 1 April 2009, dari www.antara-sumbar.com

Bapedalda Provinsi Sumbar. (2008). Kondisi Lahan Sumatera Barat. Diakses Tanggal 2 April 2009, dari Bapedalda.sumbarprov.go.id 
Dadang. U. (2007). Pembiayaaan DAS Masih Tergantung Utang Luar Negeri. Diakses tanggal 26 July 2009 dari www.tempointeraktif.com

Dharma. A. (2006). Perkembangan Kebijakan Sumberdaya Air dan Pengaruhnya Terhadap Pengelolaan Irigasi. Diakses Tanggal 13 Juli 2009 dari staffsite.gunadarma.ac.id

Herusansono. W. (2009). Pembentukan Forum Bantu Kerusakan Daerah Aliran Sungai. Direktur Jenderal Rehabilitasi Lahan dan Perhutani Sosial Departemen Kehutanan. www.kompas.com

Husein, M. H. (1995). Lingkungan Hidup. Masalah Pengelolaan dan Penegakan Hukumnya. Bumi Aksara. Jakarta

Iwanuddin. C. (2003). Kelembagaan Pengelolaan DAS Dalam Konteks Desentralisasi Di DAS Saddang dan Bilawalanae Sulawesi Selatan. Makalah. Diakses Tanggal 7 April 2009, dari.....(Missing website)

Kompas (2007). Seperempat DAS di Sumbar Kritis. Diakses Tanggal 1 April 2009. Dari www.kompas.com

Razak. A. (2007). Pengelolaan Sumberdaya Alam Berbasis Pengelolaan Daerah Aliran Sungai (Pendekatan Ekosistim dan Bioregion dalam Pengelolaan Sumberdaya Alam di Sub-DAS Merangin, DAS Batanghari, Kab. Sarolangun, Prov Jambi). Makalah Program Pasca Sarjana Program Studi Manajemen Konservasi Sumber Daya Alam dan Lingkungan, UGM, Yogyakarta. 